\title{
Coxopodopatellar syndrome
}

INSERM

\section{Source}

INSERM. (1999). Orphanet: an online rare disease and orphan drug data base.

Coxopodopatellar syndrome. ORPHA:1509

Small patella syndrome (SPS) is a very rare benign bone dysplasia affecting skeletal structures of the lower limb and the pelvis. 